\title{
Anaerobic Heat Production by the Heart*
}

\author{
William A. Neill $†$ and William E. Huckabee \\ (From the Departments of Medicine, University of Oregon Medical School, Portland, Ore., \\ and Boston University Medical School, Boston, Mass.)
}

Metabolic processes that release energy within the myocardium can be separated into aerobic metabolism, i.e., chemical reactions consuming $\mathrm{O}_{2}$, and anaerobic metabolism, defined here as chemical reactions not consuming $\mathrm{O}_{2}$, even though $\mathrm{O}_{2}$ may be present in the environment. The total energy that is set free by both types of process appears partially as heat within the myocardium and partially as mechanical work, which escapes from the heart, eventually to be dissipated as heat elsewhere in the body. For our purposes it will be convenient to express the energy transformation within the heart as follows : energy from aerobic metabolism + energy from anaerobic metabolism $=$ external work + local heat. In this equation, energy arising from either aerobic or anaerobic metabolism may contribute to the mechanical work performed by the heart.

In aerobic metabolism the amount of energy yielded per unit volume of $\mathrm{O}_{2}$ consumed varies only slightly with the type of substrate oxidized (1). Therefore, the rate of energy release from aerobic metabolism by the myocardium should bear a nearly constant relationship to its rate of $\mathrm{O}_{2}$ consumption. Furthermore, if conditions could be created experimentally where both anaerobic metabolism and external work were eliminated, heat production by the myocardium would bear a quantitative relationship to its $\mathrm{O}_{2}$ consumption. It should be possible to determine $\mathrm{O}_{2}$ consumption and heat production directly. Once their quantitative relationship was established at a time

* Submitted for publication January 20, 1966 ; accepted June 2, 1966.

Supported by U. S. Public Health Service research grants HE-08468, HE-07299-05, and HE-06297 and Massachusetts Heart Association research grant 570.

Presented in part at the meeting of The American Physiological Society, Atlantic City, N. J., April 1963.

$\dagger$ Address requests for reprints to Dr. William A. Neill, Dept. of Medicine, University of Oregon Medical School, 3181 S. W. Sam Jackson Park Rd., Portland, Ore. 97201. when aerobic metabolism was the sole source of heat, then anaerobic metabolism developing under different experimental conditions could be detected indirectly by the appearance of extra heat out of proportion to the $\mathrm{O}_{2}$ consumption. This anaerobic heat would be a nonspecific external manifestation of all chemical reactions not consuming $\mathrm{O}_{2}$ that occur in the myocardium.

This report describes the conditions that may incite production of anaerobic heat, the relative contribution of anaerobic heat to the total metabolic energy release, and the relationship of anaerobic heat to one of its possible sources, lactate formation.

The experiments reported here were carried out in the isolated heart of dogs. Contractions of the heart compressed intraventricular balloons, so that all energy from its metabolism, even that appearing temporarily as work, was converted eventually to heat within the heart. Thus, external work was eliminated. Oxygen consumption and heat production by the myocardium were determined during a stable control period when anaerobic metabolism by the myocardium was assumed to be absent. A caloric equivalent of $\mathrm{O}_{2}$ consumption was calculated from these data separately for each experiment. During subsequent periods in the experiments when anaerobic metabolism might or might not be occurring, heat that could be attributed to aerobic metabolism was calculated from the product of $\mathrm{O}_{2}$ consumption and its caloric equivalent. Heat production in excess of the heat attributed to aerobic metabolism, when an excess occurred, was defined as anaerobic heat.

\section{Methods}

Dogs were anesthetized in pairs with intravenous chloralose $(60 \mathrm{mg}$ per $\mathrm{kg}$ ). The larger of the pair (22 to 34 $\mathrm{kg}$ ) was used as support for the isolated heart. The chest of the smaller dog ( 16 to $25 \mathrm{~kg}$ ) was opened widely and the heart rapidly removed just as exsanguination of the dog was completed (exsanguination time, 2 to $3 \mathrm{~min}$ utes). The heart was immersed immediately in an ice- 
TABLE I

Metabolic data*

\begin{tabular}{|c|c|c|c|c|c|c|c|c|c|c|c|c|}
\hline $\begin{array}{l}\text { Experi- } \\
\text { ment } \\
\text { no. }\end{array}$ & Condition & CF & Art. $\mathrm{O}_{2}$ & $(a-v) \mathrm{O}_{2}$ & $(a-v) T$ & HP & HPO & AHP† & Art. L & $(a-v) L$ & Art. P & $(a-v) P$ \\
\hline \multicolumn{2}{|c|}{ Arterial hypoxemia } & $\begin{array}{l}m l / 100 \\
g \times \min \end{array}$ & \multicolumn{2}{|c|}{$\mathrm{ml} / 100 \mathrm{ml}$} & ${ }^{\circ} \mathrm{C}$ & \multicolumn{3}{|c|}{$\mathrm{cal} / 100 \mathrm{~g} \times \min$} & \multicolumn{4}{|c|}{ mmoles $/ L$} \\
\hline \multirow[t]{4}{*}{1 (fib) } & Control & 79 & 18.3 & 8.8 & -0.37 & 28.7 & 28.7 & & 3.45 & 0.26 & 0.59 & -0.04 \\
\hline & Art. $\mathrm{O}_{2} 25 \%$ sat. & 79 & 4.9 & 4.2 & -0.205 & 15.8 & 13.8 & 2.0 & 5.06 & -0.57 & 0.55 & 0.03 \\
\hline & Control & 35 & 20.6 & 10.7 & -0.49 & 16.7 & 16.7 & & 5.38 & 0.54 & 0.62 & -0.25 \\
\hline & Art. $\mathrm{O}_{2} 60 \%$ sat. & 35 & 13.4 & 8.9 & -0.395 & 13.5 & 14.0 & $(-0.5)$ & 5.02 & 0.43 & 0.57 & -0.18 \\
\hline \multirow[t]{4}{*}{2 (beat) } & Control & 56 & 20.6 & 8.6 & -0.365 & 20.0 & 20.0 & & 2.54 & 0.49 & 0.44 & -0.05 \\
\hline & Art. $\mathrm{O}_{2} 37 \%$ sat. & 56 & 8.1 & 5.7 & -0.26 & 14.2 & 13.4 & $(0.8)$ & 2.51 & 0.06 & 0.43 & -0.04 \\
\hline & Control & 30 & 20.1 & 12.0 & -0.53 & 15.5 & 15.5 & & 2.52 & 0.49 & 0.48 & -0.03 \\
\hline & Art. $\mathrm{O}_{2} 31 \%$ sat. & 30 & 6.4 & 5.7 & -0.32 & 9.2 & 7.4 & 1.8 & 3.45 & -0.54 & 0.43 & -0.12 \\
\hline \multirow[t]{4}{*}{3 (fib) } & Control & 51 & 17.6 & 9.1 & -0.455 & 22.5 & 22.5 & & 2.53 & 0.34 & 0.40 & 0.10 \\
\hline & Art. $\mathrm{O}_{2} 22 \%$ sat. & 19 & 4.8 & 4.2 & -0.355 & 6.3 & 3.9 & 2.4 & 2.24 & -2.75 & 0.27 & -0.06 \\
\hline & Art. $\mathrm{O}_{2} 20 \%$ sat. & 19 & 3.7 & 3.2 & -0.265 & 4.8 & 2.9 & 1.9 & 1.64 & -2.49 & 0.18 & -0.09 \\
\hline & Art. $\mathrm{O}_{2} 13 \%$ sat. & 13 & 2.7 & 2.2 & -0.215 & 2.6 & 1.3 & 1.3 & 2.92 & -1.93 & 0.29 & -0.02 \\
\hline \multirow[t]{2}{*}{$4(f i b)$} & Control & 59 & 19.7 & 11.3 & -0.505 & 29.1 & 29.1 & & 9.34 & 1.19 & 0.77 & -0.02 \\
\hline & Art. $\mathrm{O}_{2} 10 \%$ sat. & 77 & 2.2 & 1.8 & -0.22 & 15.8 & 6.1 & 9.7 & 11.14 & -1.72 & 0.58 & 0.22 \\
\hline \multirow[t]{2}{*}{5 (fib) } & Control & 39 & 20.5 & 11.1 & -0.51 & 19.4 & 19.4 & & 3.70 & 0.71 & 0.59 & 0.12 \\
\hline & Art. $\mathrm{O}_{2} 18 \%$ sat. & 37 & 4.0 & 3.2 & -0.215 & 7.6 & 5.4 & 2.2 & 6.66 & -0.71 & 0.66 & 0.01 \\
\hline \multirow[t]{2}{*}{$6(f i b)$} & Control & 51 & 22.9 & 12.0 & -0.545 & 27.1 & 27.1 & & 2.30 & 0.39 & 0.36 & 0.07 \\
\hline & Art. $\mathrm{O}_{2} 54 \%$ sat. & 52 & 12.6 & 7.8 & -0.46 & 23.0 & 18.1 & 4.9 & 2.67 & -0.31 & 0.39 & 0.01 \\
\hline \multicolumn{13}{|l|}{ Ischemia } \\
\hline \multirow[t]{2}{*}{$7(\mathrm{fib})$} & Control & 45 & 27.6 & 16.4 & -0.705 & 31.1 & 31.3 & & 1.97 & 0.46 & 0.32 & 0.04 \\
\hline & Decrease CF & 34 & 26.9 & 19.5 & -0.835 & 27.8 & 28.1 & $(-0.3)$ & 4.19 & 0.85 & 0.48 & 0.02 \\
\hline \multirow[t]{2}{*}{$8(f i b)$} & Control & 60 & 25.0 & 11.2 & -0.51 & 29.8 & 29.8 & & 6.37 & 1.09 & 0.78 & -0.01 \\
\hline & Decrease CF & 38 & 25.6 & 14.0 & -0.63 & 23.4 & 23.7 & $(-0.3)$ & 6.48 & 1.25 & 0.80 & -0.04 \\
\hline \multirow[t]{5}{*}{9 (beat) } & Control & 51 & 22.6 & 7.0 & -0.32 & 16.0 & 16.0 & & 2.07 & 0.23 & 0.38 & -0.06 \\
\hline & Decrease CF & 36 & 23.6 & 7.1 & -0.335 & 11.8 & 11.3 & $(0.5)$ & 1.55 & 0.23 & 0.33 & -0.04 \\
\hline & Decrease CF & 29 & 23.0 & 9.2 & -0.42 & 11.9 & 11.9 & $(0.0)$ & 1.54 & 0.18 & 0.31 & -0.06 \\
\hline & Decrease CF & 20 & 22.7 & 12.1 & -0.585 & 11.3 & 10.7 & 0.6 & 1.16 & -0.28 & 0.24 & -0.14 \\
\hline & Increase CF & 29 & 22.3 & 9.9 & -0.455 & 12.8 & 12.7 & $(0.1)$ & 1.34 & 0.10 & 0.26 & -0.11 \\
\hline \multirow[t]{3}{*}{10 (fib) } & Control & 44 & 22.4 & 17.2 & -0.76 & 32.7 & 32.7 & & 5.25 & 2.12 & 0.48 & 0.12 \\
\hline & Decrease CF & 11 & 21.3 & 17.9 & -0.87 & 9.3 & 8.5 & 0.8 & 7.86 & -1.33 & 0.65 & 0.30 \\
\hline & $\begin{array}{l}\text { Increase } \mathrm{CF} \\
\quad \text { (Art. } \mathrm{O}_{2} 36 \% \text { sat.) }\end{array}$ & 60 & 8.8 & 5.5 & -0.26 & 15.2 & 14.1 & $(1.1)$ & 8.05 & 0.48 & 0.47 & -0.40 \\
\hline \multicolumn{13}{|c|}{ Cyanide infusion } \\
\hline \multirow[t]{3}{*}{11 (beat) } & Control & 45 & 25.9 & 9.9 & -0.40 & 17.7 & 17.7 & & 3.56 & 0.83 & 0.54 & 0.05 \\
\hline & $0.28 \mathrm{mEq} / \mathrm{L}$ & 46 & 25.6 & 4.1 & -0.22 & 9.8 & 7.6 & 2.2 & 3.79 & -1.00 & 0.54 & 0.09 \\
\hline & $0.46 \mathrm{mEq} / \mathrm{L}$ & 46 & 27.7 & 3.0 & -0.23 & 10.0 & 5.5 & 4.5 & 4.67 & -3.29 & 0.45 & 0.15 \\
\hline \multirow[t]{3}{*}{12 (fib) } & Control & 57 & 23.2 & 8.0 & -0.345 & 19.2 & 19.2 & & 3.29 & 0.17 & 0.50 & -0.06 \\
\hline & $0.12 \mathrm{mEq} / \mathrm{L}$ & 57 & 23.3 & 4.4 & -0.25 & 13.8 & 10.6 & 3.2 & 3.29 & -1.83 & 0.43 & 0.09 \\
\hline & $0.30 \mathrm{mEq} / \mathrm{L}$ & 56 & 23.7 & 1.1 & -0.105 & 5.6 & 2.7 & 2.9 & 4.01 & -1.56 & 0.38 & 0.09 \\
\hline 13 (beat) & Control & 62 & 22.8 & 10.2 & -0.415 & 25.3 & 25.3 & & 3.42 & 0.61 & 0.54 & 0.07 \\
\hline & $0.20 \mathrm{mEq} / \mathrm{L}$ & 66 & 22.7 & 2.8 & -0.14 & 9.0 & 7.4 & 1.6 & 3.87 & -1.65 & 0.50 & -0.01 \\
\hline 14 (beat) & Control & 61 & 21.9 & 12.3 & -0.58 & 34.5 & 34.5 & & 6.59 & 0.94 & 0.71 & 0.15 \\
\hline & $0.09 \mathrm{mEq} / \mathrm{L}$ & 63 & 21.3 & 8.0 & -0.41 & 25.0 & 22.9 & 2.1 & 7.13 & -0.48 & 0.73 & 0.15 \\
\hline & $0.11 \mathrm{mEq} / \mathrm{L}$ & 63 & 20.6 & 5.1 & -0.31 & 18.8 & 14.8 & 4.0 & 8.19 & -1.33 & 0.70 & 0.06 \\
\hline & $0.23 \mathrm{mEq} / \mathrm{L}$ & 63 & 21.9 & 1.9 & -0.21 & 12.4 & 5.4 & 7.0 & 11.66 & -2.75 & 0.52 & 0.13 \\
\hline 15 (beat) & Control & 49 & 21.5 & 10.8 & -0.48 & 23.0 & 23.0 & & 2.35 & 0.84 & 0.37 & 0.12 \\
\hline & $0.12 \mathrm{mEq} / \mathrm{L} 22 \mathrm{~min}$ & 51 & 21.6 & 5.3 & -0.335 & 16.4 & 11.8 & 4.6 & 2.71 & -1.28 & 0.35 & 0.08 \\
\hline & $0.12 \mathrm{mEq} / \mathrm{L} 35 \mathrm{~min}$ & 51 & 21.6 & 4.6 & -0.315 & 15.3 & 10.1 & 5.2 & 2.77 & -1.12 & 0.37 & 0.07 \\
\hline
\end{tabular}

* Abbreviations: $\mathrm{CF}=$ coronary blood flow $;$ art. $=$ arterial blood $; \mathrm{a}-\mathrm{v}=$ arteriovenous difference; $\mathrm{T}=$ blood temperature $; \mathrm{HP}=\mathrm{myocardial}$ total heat production; HPO = myocardial heat production from aerobic metabolism; AHP = myocardial heat production from anaerobic metabolism; $L=$ lactate; $P=$ pyruvate; fib = experiments with ventricular fibrillation; and beat = experiments with regular ventricular contractions.

$f$ Parentheses indicate that the figure for anaerobic heat is within the experimental error ( $\pm 0.02 \mathrm{cal}$ per ml coronary blood flow). 
TABLE I-(Continued $)$

\begin{tabular}{|c|c|c|c|c|c|c|c|c|c|c|c|c|}
\hline $\begin{array}{c}\text { Experi- } \\
\text { ment } \\
\text { no. }\end{array}$ & Condition & $\mathrm{CF}$ & Art. $\mathrm{O}_{2}$ & $(\mathrm{a}-\mathrm{v}) \mathrm{O}_{2}$ & $(a-v) T$ & HP & HPO & AHP† & Art. L & $(a-v) L$ & Art. P & $(a-v) P$ \\
\hline & & $\begin{array}{l}\mathrm{ml} / 100 \\
\mathrm{~g} \times \min \end{array}$ & \multicolumn{2}{|c|}{$\mathrm{ml} / 100 \mathrm{ml}$} & ${ }^{\circ} \mathrm{C}$ & \multicolumn{3}{|c|}{$\mathrm{cal} / 100 \mathrm{~g} \times \min$} & \multicolumn{4}{|c|}{ mmoles $/ L$} \\
\hline \multicolumn{13}{|c|}{ Arterial alkalization } \\
\hline \multirow[t]{4}{*}{16 (beat) } & Control pH 7.32 & 66 & 23.2 & 8.6 & -0.43 & 27.5 & 27.5 & & 1.71 & 0.19 & 0.35 & 0.05 \\
\hline & $\mathrm{pH} 7.43$ & 66 & 23.1 & 9.2 & -0.45 & 28.8 & 29.7 & $(-0.9)$ & 1.65 & 0.07 & 0.32 & 0.05 \\
\hline & $\mathrm{pH} 7.47$ & 68 & 21.7 & 9.3 & -0.46 & 30.3 & 30.9 & $(-0.6)$ & 1.60 & 0.18 & 0.31 & 0.06 \\
\hline & pH 7.48 & 68 & 21.6 & 9.8 & -0.485 & 32.0 & 32.5 & $(-0.5)$ & 1.57 & 0.09 & 0.33 & 0.05 \\
\hline \multirow[t]{4}{*}{17 (beat) } & Control pH 7.31 & 58 & 22.4 & 7.1 & -0.32 & 18.1 & 18.1 & & 1.82 & 0.21 & 0.32 & 0.02 \\
\hline & pH 7.97 & 59 & 23.0 & 10.8 & -0.525 & 30.1 & 28.1 & 2.0 & 2.36 & -0.39 & 0.40 & -0.15 \\
\hline & pH 7.97 & 59 & 22.8 & 10.1 & -0.515 & 29.4 & 26.3 & 3.1 & 2.52 & -0.40 & 0.40 & -0.14 \\
\hline & pH 8.02 & 59 & 23.0 & 10.0 & -0.52 & 29.7 & 25.8 & 3.9 & 2.93 & -0.39 & 0.45 & -0.14 \\
\hline \multirow[t]{4}{*}{$18(f i b)$} & Control pH 7.27 & 59 & 19.2 & 7.9 & -0.375 & 21.5 & 21.5 & $\therefore$ & 1.38 & 0.20 & 0.27 & 0.00 \\
\hline & $\mathrm{pH} 7.52$ & 59 & 17.5 & 9.0 & -0.46 & 26.3 & 24.4 & 1.9 & 1.40 & -0.45 & 0.26 & -0.11 \\
\hline & $\mathrm{pH} 8.00$ & 60 & 17.0 & 9.7 & -0.51 & 29.5 & 26.8 & 2.7 & 1.70 & -1.16 & 0.30 & -0.40 \\
\hline & $\mathrm{pH} 7.29$ & 59 & 17.7 & 8.3 & -0.405 & 23.2 & 22.6 & $(0.6)$ & 1.42 & 0.32 & 0.25 & -0.03 \\
\hline \multirow[t]{3}{*}{19 (beat) } & Control $\mathrm{pH} 7.41$ & 47 & 22.0 & 8.3 & -0.385 & 17.7 & 17.7 & & 2.59 & 0.18 & 0.39 & -0.06 \\
\hline & $\mathrm{pH} 7.75$ & 48 & 21.1 & 8.3 & -0.40 & 18.7 & 18.1 & $(0.6)$ & 2.51 & -0.20 & 0.42 & -0.17 \\
\hline & pH 8.18 & 48 & 21.0 & 9.3 & -0.46 & 21.4 & 20.3 & 1.1 & 2.71 & -0.58 & 0.46 & -0.32 \\
\hline \multirow[t]{4}{*}{20 (beat) } & Control pH 7.41 & 48 & 22.2 & 11.1 & -0.52 & 24.3 & 24.3 & & 3.39 & 0.71 & 0.57 & 0.17 \\
\hline & pH 7.86 & 48 & 21.3 & 14.3 & -0.735 & 34.1 & 31.1 & 3.0 & 3.60 & -0.63 & 0.55 & -0.17 \\
\hline & pH 8.37 & 48 & 20.3 & 13.5 & -0.73 & 33.8 & 29.2 & 4.6 & 3.83 & -3.04 & 0.61 & -0.87 \\
\hline & pH 7.36 & 48 & 21.3 & 7.9 & -0.385 & 17.9 & 17.3 & $(0.6)$ & 3.81 & 0.35 & 0.55 & -0.10 \\
\hline
\end{tabular}

saline mixture where it remained while being prepared for perfusion ( 20 to 35 minutes). A balloon was secured within the right ventricle via the pulmonary artery, and another balloon and thebesian drainage cannula were secured within the left ventricle via the mitral ring. The inferior vena cava and azygous vein were ligated, and a cannula for coronary venous drainage was inserted via the superior vena cava.

For coronary perfusion, blood was pumped by a Sigma motor directly from the carotid artery of the support dog retrograde into the ascending aorta of the isolated heart. A plastic disc tied into the aortic ring below the coronary ostia prevented arterial blood from entering the left ventricular cavity. Coronary venous blood was drained by gravity into a reservoir and returned continuously to the support dog.

The heart was suspended in air in a double-walled chamber totally immersed in a constant temperature water bath. The blood for coronary perfusion passed through a thin-walled stainless steel coil also immersed in the water bath. The temperature of coronary arterial blood was kept constant within $0.01^{\circ} \mathrm{C}$ and myocardial surface heat loss maintained at a small and nearly constant value (see Discussion). Coronary arterial and venous blood temperatures were measured by thermistors in the coronary blood streams entering and leaving the isolated heart. The arterial and venous thermistors were oriented similarly in tubes of equal diameter so that they were subjected to the same velocity of blood flow. The error of estimating the blood arterialvenous (a-v) temperature difference was approximately $\pm 0.01^{\circ} \mathrm{C}(2)$.

Coronary arterial and venous blood samples were taken over a 3-minute period from sidearm tubes. Blood $\mathrm{O}_{2}$ content was determined by the manometric method (3), and $\mathrm{O}_{2}$ saturation was calculated. Blood lactate and pyruvate concentrations were determined by previously described modifications (4) of the methods of Barker and Summerson, and Friedemann and Haugen, respectively. $\mathrm{pH}$ was determined by a glass electrode. Coronary perfusion pressure was measured by a Sanborn strain gauge. To measure coronary blood flow, we diverted venous drainage into a graduated cylinder for 1 minute. Repeat determinations did not differ by more than $1 \mathrm{ml}$ per minute. Thebesian venous drainage from the left ventricular cavity, which never exceeded $2 \%$ of coronary blood flow, was not included. Coronary flow is expressed in milliliters of blood per $100 \mathrm{~g}$ combined ventricular weight, virtually all of the atrial tissue having been cut away or excluded by ligatures (ventricular weight, 85 to $206 \mathrm{~g}$; mean, $160 \mathrm{~g}$ ).

In ten experiments the heart was fibrillating, and in ten it was paced at a uniform rate by electric stimulation. Contractions of the heart compressed the intraventricular balloons, which were partially filled by air (left 15 to $25 \mathrm{ml}$, right $5 \mathrm{ml}$ ). Thus, all energy released by myocardial metabolism, including the portion appearing transiently as mechanical work, was converted to heat within the heart.

Control observations were made only after the coronary a-v temperature difference had been steady (within $0.02^{\circ} \mathrm{C}$ ) for at least 20 minutes. A minimum of $15 \mathrm{~min}$ utes $^{1}$ was allowed for equilibration after a change in

1 The time lag for equilibration of coronary venous blood temperature with, for example, an arțificial change 
experimental conditions, and calculations of heat production are based only on observations made with stable coronary arterial and venous temperatures (temperature change $<0.01^{\circ} \mathrm{C}$ per minute).

$\mathrm{O}_{2}$ consumption by the myocardium and uptake or output of lactate and pyruvate by the myocardium were calculated from the product of the coronary blood flow and the coronary a-v differences in blood concentrations of $\mathrm{O}_{2} \quad\left[(\mathrm{a}-\mathrm{v}) \mathrm{O}_{2}\right]$, lactate $[(\mathrm{a}-\mathrm{v}) \mathrm{L}]$, and pyruvate $[(\mathrm{a}-\mathrm{v}) \mathrm{P}]$, respectively.

The caloric equivalent of $\mathrm{O}_{3}$ consumption was calculated separately for each experiment from its own control data: (1) cal. eq. $\mathrm{O}_{2}=[-$ control (a-v) $\mathrm{T} \times .91 \times$ $100] /\left[\right.$ control $\left.(\mathrm{a}-\mathrm{v}) \mathrm{O}_{2}\right]+0.3$, where cal. eq. $\mathrm{O}_{2}=$ caloric equivalent of $\mathrm{O}_{2}$ consumption in calories per $\mathrm{ml} \mathrm{O}_{2}$; (a-v) $\mathrm{T}=$ coronary $\mathrm{a}-\mathrm{v}$ difference in blood temperature in degrees Centigrade; $(\mathrm{a}-\mathrm{v}) \mathrm{O}_{2}=$ milliliters $\mathrm{O}_{2}$ per 100 $\mathrm{ml}$ blood; $0.3=$ adjustment for hemoglobin deoxygenation, which is an endothermic reaction absorbing $0.3 \mathrm{cal}$ per milliliter $\mathrm{O}_{2}$ released $(2,5)$; and $0.91=$ specific heat $X$ density of blood.

Heat from aerobic metabolism by the myocardium during subsequent experimental periods was calculated as the product of $\mathrm{O}_{2}$ consumption and the caloric equivalent of $\mathrm{O}_{2}$ consumption: (2) $\mathrm{HPO}=\left[(\mathrm{a}-\mathrm{v}) \mathrm{O}_{2} / 100\right] \times \mathrm{CF} \times$ cal. eq. $\mathrm{O}_{2}$, where $\mathrm{HPO}=$ heat produced by aerobic metabolism in calories per $100 \mathrm{~g} \times$ minutes, and $\mathrm{CF}=$ coronary blood flow in milliliters per $100 \mathrm{~g} \times$ minutes.

Total heat production by the myocardium was calculated from the heat removed by the coronary blood plus the heat absorbed by deoxygenation of hemoglobin: (3) $\mathrm{HP}=-(\mathrm{a}-\mathrm{v}) \mathrm{T} \times .91 \times \mathrm{CF}+\left[(\mathrm{a}-\mathrm{v}) \mathrm{O}_{2} / 100\right] \times \mathrm{CF} \times 0.3$, where $\mathrm{HP}=$ total heat produced by metabolism in calories per $100 \mathrm{~g} \times$ minutes.

Anaerobic heat production was calculated by subtracting the heat produced by aerobic metabolism from the total heat: (4) $\mathrm{AHP}=\mathrm{HP}-\mathrm{HPO}$, where $\mathrm{AHP}=$ anaerobic heat production in calories per $100 \mathrm{~g} \times$ minutes.

The accuracy of calculated anaerobic heat depends mainly upon the accuracy of $(\mathrm{a}-\mathrm{v}) \mathrm{O}_{2}( \pm 0.2 \mathrm{ml}$ per 100 $\mathrm{ml})$ and $(\mathrm{a}-\mathrm{v}) \mathrm{T}\left( \pm 0.01^{\circ} \mathrm{C}\right)$, representing potential errors of \pm 0.01 and \pm 0.01 cal per $\mathrm{ml}$ blood flow, respectively. Thus, anaerobic heat of $0.02 \mathrm{cal}$ per $\mathrm{ml}$ blood (or $1.2 \mathrm{cal}$ per $100 \mathrm{~g} \times$ minutes at a typical coronary blood flow of $60 \mathrm{ml}$ per $100 \mathrm{~g} \times$ minutes) should be the approximate limit of experimental error. ${ }^{2}$

\section{Results}

Data are given in Table I.

Control period. During 22 control periods in 20 hearts, coronary blood flow to the isolated heart was set at varied levels within a range

in arterial blood temperature of $1^{\circ} \mathrm{C}$ was approximately 10 minutes at a coronary blood flow of $60 \mathrm{ml}$ per minute and 15 minutes when coronary flow was reduced to $30 \mathrm{ml}$ per minute.

2 Additional possible error from variation in extracoronary heat loss is discussed later.

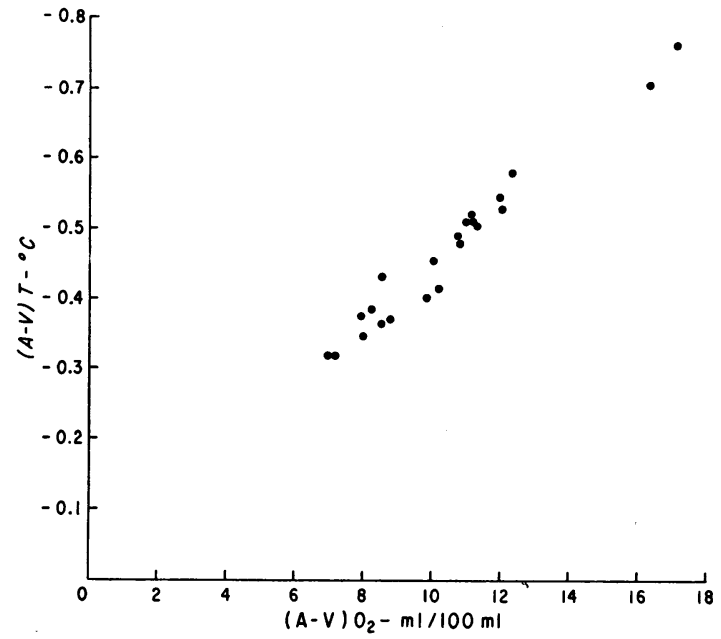

Fig. 1. The Relationship Between the A-V DifFERENCES FOR $\mathrm{O}_{2}$ AND TEMPERATURE IN THE CORONARY BLOOD DURING THE CONTROL PERIOD. Each point represents the data of a separate experiment and forms the basis for calculation of the caloric equivalent of $\mathrm{O}_{2}$ consumption for that experiment. $a-v=$ arterial-venous; $\mathrm{T}=$ blood temperature.

of 30 to $79 \mathrm{ml}$ per $100 \mathrm{~g} \times$ minutes. Coronary perfusion pressure (mean of pulsatile pressure) ranged from 65 to $152 \mathrm{~mm} \mathrm{Hg}$. Oxygen saturation of arterial blood was above $89 \%$, and $\mathrm{O}_{2}$ saturation of coronary venous blood ranged from 21 to $65 \%$ (mean $50 \%$ ).

With control perfusion, lactate was absorbed from the coronary blood by the myocardium, resulting in a positive (a-v)L during each control period. The (a-v) $\mathrm{P}$ was variable, positive and negative values being equally frequent. The ratio of the concentration of lactate to the concentration of pyruvate (L/P ratio) was lower in coronary venous blood (mean 6.1) than in arterial blood (mean 6.9) in 16 of the 22 controls.

The relationship between the control coronary blood (a-v) $\mathrm{O}_{2}$ (range 7.0 to $17.2 \mathrm{ml} \mathrm{O}_{2}$ per 100 $\mathrm{ml}$ ) and (a-v) T (range -0.32 to $-0.76^{\circ} \mathrm{C}$ ) is presented in Figure 1. The caloric equivalent of $\mathrm{O}_{2}$ consumption by the myocardium (first equation in Methods) calculated from these data was 4.40 cal per $\mathrm{ml} \mathrm{O}_{2}(\mathrm{SD} \pm 0.20)$. The caloric equivalent was the same whether the heart was rhythmically contracting (4.39) or fibrillating (4.41) and was not influenced by the coronary blood flow rate (high flow 4.34 ; low flow 4.46) or (a-v) T [large (a-v) T, 4.42; small (a-v) T, 4.381. 


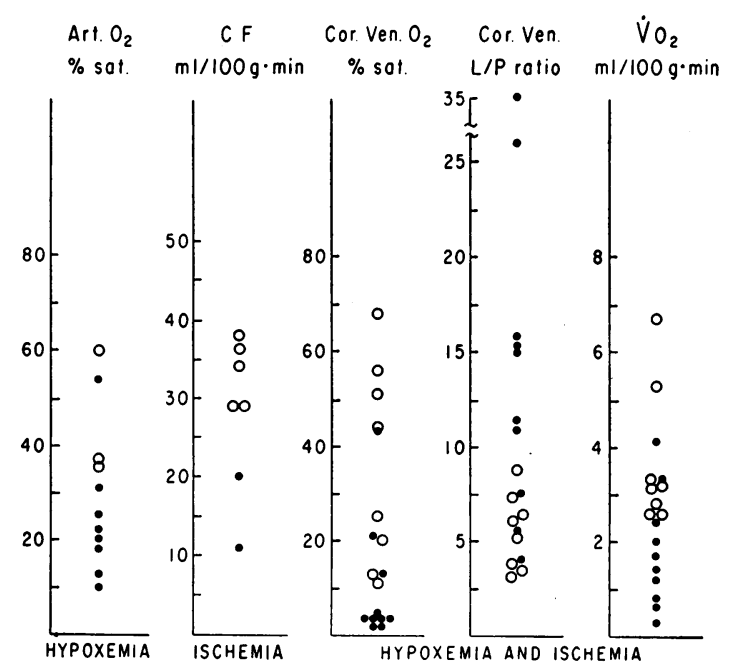

Fig. 2. THE RELATIONSHIP BET.WEEN SIGNS OF REDUCED $\mathrm{O}_{2}$ SUPPLY TO THE MYOCARDIUM AND THE DEVELOPMENT OF ANAEROBIC HEAT. $O=$ no anaerobic heat; $0=$ anaerobic heat production; $\mathrm{CF}=$ coronary blood flow ; $\mathrm{L} / \mathrm{P}$ $=$ lactate to pyruvate concentration ratio; $\dot{V O}_{2}=\mathrm{O}_{2}$ consumption.

Myocardial hypoxia. In 18 observations (10 hearts) the rate of supply of $\mathrm{O}_{2}$ to the myocardium was diminished by reduction either in the rate of coronary blood flow or in the $\mathrm{O}_{2}$ saturation of the coronary arterial blood (arterial hypoxemia). ${ }^{3}$ In 10 other observations ( 6 hearts) $\mathrm{O}_{2}$ supply via the blood was unchanged, but $\mathrm{O}_{2}$ metabolism by the myocardium was partially inhibited by steady infusion of $\mathrm{NaCN}$ into the coronary arterial blood.

Diminished $\mathrm{O}_{2}$ supply via the coronary blood decreased the rates of both $\mathrm{O}_{2}$ consumption and heat production by the myocardium. In 8 of these 18 observation periods, $\mathrm{O}_{2}$ consumption and heat production decreased proportionately (mean decreases $27 \%$ and $26 \%$, respectively). In each of the remaining 10 instances, however, the decrease in $\mathrm{O}_{2}$ consumption (mean decrease $66 \%$ ) was proportionately greater than the decrease in heat production (mean decrease $54 \%$ ), indicating the development of a new, anaerobic source of heat by the myocardium (fourth equation in Methods).

The development of anaerobic heat was correlated with the degree of reduction in $\mathrm{O}_{2}$ delivery via the blood, as well as with certain factors that may indicate the extent of reduction in $\mathrm{O}_{2}$ supply

${ }^{3}$ By perfusion with venous blood from the support dog. for myocardial metabolism (Figure 2). Anaerobic heat occurred uniformly when coronary venous blood $\mathrm{O}_{2}$ saturation fell below $10 \%$, coronary venous blood $\mathrm{L} / \mathrm{P}$ ratio rose above 10 , or myocardial $\mathrm{O}_{2}$ consumption fell below $2.5 \mathrm{ml}$ per $100 \mathrm{~g} \times$ minutes (Figure 2, solid dots). These changes are ordinarily interpreted as evidence for tissue hypoxia. In the same experiments, however, when similar signs of tissue hypoxia were present, but less marked, anaerobic heat production usually did not occur (Figure 2, open circles).

When the reduction in $\mathrm{O}_{2}$ supply in these experiments did not result in anaerobic heat, (a-v) $\mathrm{L}$ remained positive, despite rises in coronary venous blood lactate concentration and $\mathrm{L} / \mathrm{P}$ ratio in four of the eight instances. On the other hand, when anaerobic heat did appear, (a-v) L always became negative. Lactate uptake was reversed to lactate output by the myocardium into the blood. Changes in $(\mathrm{a}-\mathrm{v}) \mathrm{P}$ were variable and not correlated with the development of anaerobic heat.

Infusion of low concentrations of $\mathrm{NaCN}$ into the coronary arterial blood reduced the rate of $\mathrm{O}_{2}$ consumption by the myocardium. The decrease in $\mathrm{O}_{2}$ consumption (mean decrease $60 \%$ ) was in each instance proportionately greater than the decrease in heat production (mean decrease $44 \%$ ), the difference representing the appearance of anaerobic heat. $\mathrm{O}_{2}$ saturation of coronary venous blood was increased rather than decreased, but other signs of myocardial hypoxia (increase in coronary venous blood $\mathrm{L} / \mathrm{P}$ ratio and decrease in myocardial $\mathrm{O}_{2}$ consumption) were uniformly present. (a-v) $\mathrm{L}$ became negative in each instance, whereas no consistent change occurred in $(a-v) P$.

The maximal rate of anaerobic heat production was $9.7 \mathrm{cal}$ per $100 \mathrm{~g} \times$ minutes, equivalent calorically to approximately $2 \mathrm{ml} \mathrm{O}_{2}$. The anaerobic portion of the total metabolic rate by the myocardium depended partly upon the degree of decrease in its aerobic metabolism (Figure 3). Moderate decreases in $\mathrm{O}_{2}$ consumption resulted in anaerobic heat production in slightly less than half the observations. With decrease in $\mathrm{O}_{2}$ consumption to below $2.5 \mathrm{ml}$ per $100 \mathrm{~g} \times$ minutes, whether due to reduced $\mathrm{O}_{2}$ supply or inhibition of $\mathrm{O}_{2}$ metabolism by $\mathrm{NaCN}$, anaerobic heat appeared consistently. With this marked reduction in aerobic metabolism, the mean rate of anaerobic heat production was $3.5 \mathrm{cal}$ per $100 \mathrm{~g} \times$ minutes, 
equivalent calorically to $0.8 \mathrm{ml} \mathrm{O}_{2}$ and comprising an average of $\frac{1}{3}$ ( 5 to $60 \%$ ) of the total rate of metabolism by the myocardium.

Alkalization. Reduction in arterial blood $\mathrm{H}^{+}$ from 48 nanomoles per $\mathrm{L}(\mathrm{pH} 7.32)$ to 37 to 33 nanomoles per $\mathrm{L}$ ( $\mathrm{pH} 7.43$ to 7.48 ) caused increases in myocardial $\mathrm{O}_{2}$ consumption ${ }^{4}$ and heat production that were proportional (mean increases 12 and $11 \%$, respectively) and caused no significant shange in (a-v) $\mathrm{L}$ or $(\mathrm{a}-\mathrm{v}) \mathrm{P}$ (three observations in one heart). With further reduction in arterial blood $\mathrm{H}^{+}$to 30 to 4 nanomoles per $\mathrm{L}(\mathrm{pH}$ 7.52 to 8.37 ), the increase in myocardial $\mathrm{O}_{2}$ consumption, although larger (mean increase $27 \%$ ), was not so great as the increase in heat production (mean increase $38 \%$ ), indicating production of heat anaerobically (nine observations in three hearts). Lactate output [negative (a-v)L] occurred in each instance, but in contrast to the hypoxia experiments, pyruvate output [negative (a-v)P] also occurred. Therefore, with alkalization, the $\mathrm{L} / \mathrm{P}$ ratio in the coronary venous blood

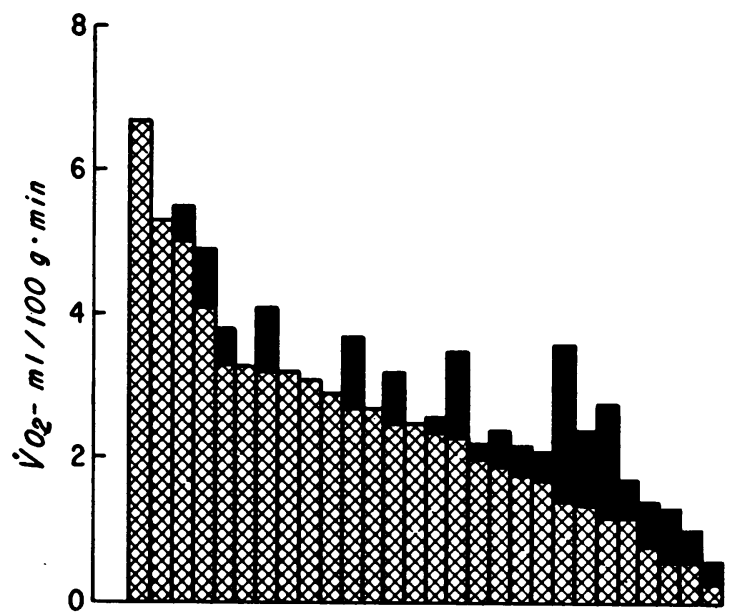

Fig. 3. THE EFFECT OF INHIBITION OF AEROBIC METABOLISM ON THE COMPENSATORY INITIATION OF ANAEROBIC METABOLISM. Each vertical bar represents an observation during arterial hypoxemia, ischemia, or cyanide administration. The shaded portion of each bar depicts the aerobic metabolic rate. The solid portion depicts the anaerobic metabolic rate plotted on a scale that is comparable to $\mathrm{O}_{2}$ on a caloric basis ( $1 \mathrm{ml} \mathrm{O}_{2}=$ 4.4 cal).

4 Stimulation of $\mathrm{O}_{2}$ consumption and glycolysis due to reduction in $\mathrm{H}^{+}$has been observed in cell suspension preparations (6).

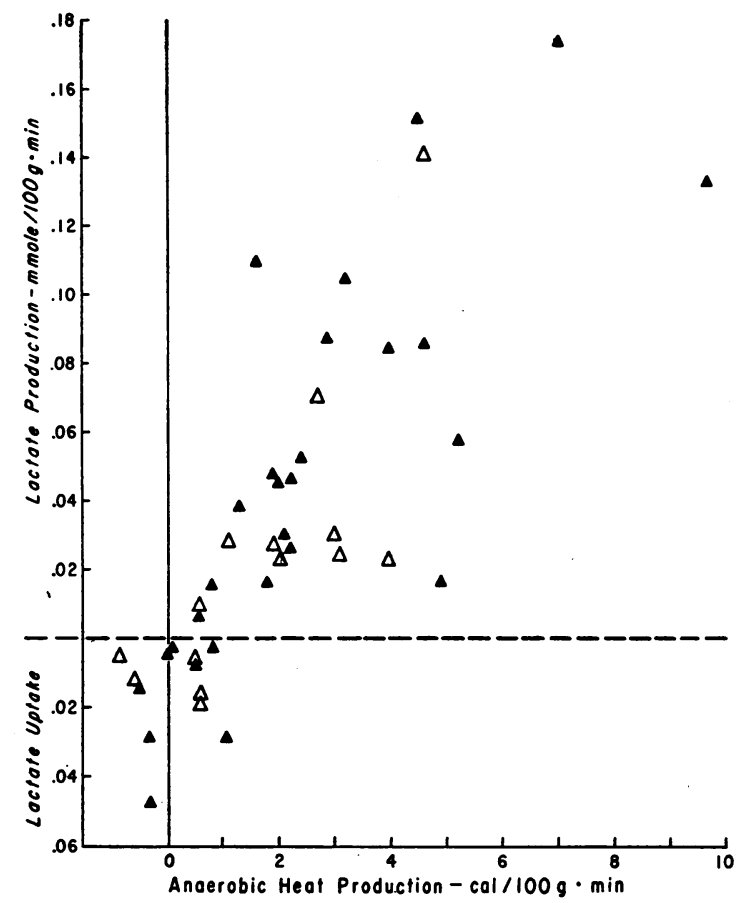

Fig. 4. The relationship between lactate and ANAEROBIC HEAT PRODUCED BY THE MYOCARDIUM. $\boldsymbol{\Delta}=$ arterial hypoxemia, ischemia, or cyanide administration; $\Delta=$ arterial alkalization. The development of anaerobic heat was accompanied by reversal from lactate uptake to lactate production by the myocardium.

was not increased (control mean venous $\mathrm{L} / \mathrm{P}$ ratio, 5.4 ; alkalization, 5.2).

The relationship between anaerobic heat and (a-v) L is illustrated in Figure 4. All experiments are included, those with myocardial hypoxia (solid triangles) as well as those with alkalization (open triangles). Note that initiation of anaerobic heat was accompanied by output of lactate by the heart, although in the same experiments when anaerobic heat did not develop, (a-v)L remained positive.

\section{Discussion}

The presence of anaerobic heat production, as determined in these experiments, is based upon the appearance of heat out of proportion to the myocardial $\mathrm{O}_{2}$ consumption, the expected proportion to $\mathrm{O}_{2}$ consumption having been established during a control period when aerobic metabolism was assumed to be the sole source of heat. Although there is nothing to suggest that other sources of heat were present during the control period, de- 
tection of anaerobic heat by the subsequent appearance of excess heat in comparison to a reference control period actually does not require that all processes involving gain or loss of heat during the control period necessarily be accounted for, provided these processes are consistently present throughout the duration of the experiment.

For example, heat loss from the surface of the heart, which was omitted from calculation of myocardial heat production, will lead to an underestimation of the caloric equivalent of $\mathrm{O}_{2}$ consumption but will not affect the detection of anaerobic heat, provided the fraction of heat loss from the surface remains constant. An estimate of the magnitude of surface heat loss can be made by comparison of the caloric equivalent of $\mathrm{O}_{2}$ consumption found in these experiments, $4.4 \mathrm{cal}$ per $\mathrm{ml} \mathrm{O}_{2}$, with the thoretical value, approximately $4.8 \mathrm{cal}$ per $\mathrm{ml} \mathrm{O}_{2} .{ }^{5}$ The difference of $0.4 \mathrm{cal}$ (or $8 \%$ ) presumably represents, at least in part, surface heat loss. Variations in coronary blood flow or in (a-v) $\mathrm{T}$ that might have been expected to disturb the distribution of heat lost by different routes did not, in fact, alter the calculated caloric equivalent of $\mathrm{O}_{2}$ consumption and, therefore, apparently did not measurably affect the small fraction of total heat production that was lost from the surface of the insulated isolated heart. This important difference from the findings in the heart of the intact dog undoubtedly is due to the large extracoronary heat loss at low rates of coronary blood flow in the intact animal (2).

The work that each contraction by the myocardium performed in compressing the intraventricular balloons was not cumulative and had no way to escape from the heart. The presumption that this work ultimately was converted to heat within the heart is substantiated by the fact that the caloric equivalent of $\mathrm{O}_{2}$ consumption was not less in the experiments with the heart contracting than in those with the heart fibrillating.

Reduction in $\mathrm{O}_{2}$ supply to the myocardium led regularly to signs of tissue hypoxia, including decrease in its rate of $\mathrm{O}_{2}$ consumption. When $\mathrm{O}_{2}$ consumption fell to a level below $2.5 \mathrm{ml}$ per $100 \mathrm{~g}$ $\times$ minutes, the decrease in the rate of energy release by aerobic metabolism was offset partially by

54.7 to 5.0 (1), depending upon the substrate oxidized. The value should be approximately 4.8 for the usual substrate mixture of the myocardium (7). the initiation of compensatory metabolic processes releasing energy or heat anaerobically, the anaerobic metabolism on a caloric basis amounting to as much as half the total metabolic rate (Figure 3 ). When aerobic metabolism is restricted to this extent, anaerobic metabolism appears to provide a sizable portion of the total metabolic energy release that would be available for conversion to mechanical work of the heart. With myocardial hypoxia and less marked decrease in $\mathrm{O}_{2}$ consumption, however, the development of anaerobic metabolism was inconstant. Anaerobic heat appeared in some instances but not in others.

When anaerobic heat did appear, the direction of the $(a-v) L$ was reversed from positive to negative (Figure 4). The direction of the (a-v)L depends upon the direction of movement of lactate between myocardium and coronary blood. Under control conditions, the (a-v) L was positive; lactate moved from the blood into the myocardium where it was consumed. When $\mathrm{O}_{2}$ supply to the heart was reduced, the lactate concentration in the coronary venous blood rose, resulting in one of the following changes in $(\mathrm{a}-\mathrm{v}) \mathrm{L}: 1)$ reduction in the magnitude of the positive (a-v) L, or 2) reversal from a positive to a negative $(\mathrm{a}-\mathrm{v}) \mathrm{L}$. The latter, the appearance of a negative $(a-v) L$ or lactate loss from the heart, was accompanied by the appearance of anaerobic heat from the heart. Both the negative (a-v) $L$ and the anaerobic heat are external signs of the onset of anaerobic metabolism within the myocardium. On the other hand, reduction in the magnitude of the positive (a-v)L does not indicate that new anaerobic chemical processes of a continuous nature have begun. The higher coronary venous blood lactate concentration that is responsible for the reduced (a-v)L does suggest an increase in myocardial lactate concentration, which may well be related to diminished availability of $\mathrm{O}_{2}$ for aerobic metabolism. Nevertheless, provided a steady state (i.e., constant lactate concentrations in myocardium and blood) has been reached, a positive (a-v)L, irrespective of its magnitude, indicates lactate uptake by the myocardium. If it is assumed that lactate does not accumulate in the tissue, continued uptake is not compatible with lactate formation as a sustained source of anaerobic energy. Absence of anaerobic metabolism under these circumstances was, in fact, substantiated by the absence of an- 
aerobic heat as long as the (a-v)L remained positive.

Anaerobic heat induced by alkalization also was accompanied by reversal in the $(\mathrm{a}-\mathrm{v}) \mathrm{L}$. This observation emphasizes that lactate output by the heart into the blood is a manifestation of lactate production within the myocardium that liberates energy anaerobically without regard to the presence or absence of myocardial hypoxia.

The alkalization experiments also provide another type of information. With alkalization the anaerobic heat occurred with rising coronary venous blood temperature. Failure to reach steady myocardial and coronary venous blood temperatures, which would have resulted in overestimation of anaerobic heat in the hypoxia experiments, would lead to an error in the opposite direction in the alkalization experiments. Yet, there was no obvious quantitative difference in the relationship between anaerobic heat and lactate output in the observations with hypoxia compared to those with alkalization (Figure 4).

If the anaerobic heat was due exclusively to lactate formation, one would expect that the anaerobic heat in calories per minute divided by the concurrent lactate output in millimoles per minute would be comparable to the reaction heat of glycolysis, $\Delta \mathrm{H}=-18$ cal per mmole lactate (8). The anaerobic caloric equivalent of lactate output calculated in this way varied in these experiments from 16 to 100 cal per mmole lactate. The median value was 50 cal. A comparably high value was found also in previous experiments in the intact dog (9). Although the figure of $50 \mathrm{cal}$ per mmole lactate is subject to relatively large experimental error, it is of a sufficiently different order of magnitude from the glycolysis heat to suggest at least the possibility of some other in vivo sources of anaerobic heat. One source is neutralization of the lactic acid formed in metabolism, which could account for from 1.5 to $13 \mathrm{cal}$ of anaerobic heat per mmole lactate, depending upon the reactions involved (10). Anaerobic heat may also have arisen on a temporary basis from previously stored energy sources, e.g., hydrolysis of creatine phosphate and ATP, or possibly on a continuing basis from unidentified anaerobic metabolic processes in addition to lactate formation.

\section{Summary}

The coronary system of the isolated dog heart was perfused with blood from a separate intact dog. Contractions of the isolated heart compressed intraventricular balloons so that external work was prevented and all energy from its metabolism was converted to heat within the heart. The heart was insulated, and myocardial heat production was determined from the heat removed via the coronary blood.

During a stable control period, the myocardium consumed lactate taken up from the blood, and heat production by the myocardium was proportional to its $\mathrm{O}_{2}$ consumption (caloric equivalent of $\mathrm{O}_{2}$ consumption, 4.4 cal per $\mathrm{ml} \mathrm{O}_{2}$ ). Anaerobic heat during subsequent experimental conditions was determined by the appearance of extra heat out of proportion to the $\mathrm{O}_{2}$ consumption.

Decrease in $\mathrm{O}_{2}$ supply via the coronary blood or partial inhibition of $\mathrm{O}_{2}$ utilization by cyanide administration caused a fall in myocardial $\mathrm{O}_{2}$ consumption and a rise in the lactate/pyruvate concentration ratio in the coronary venous blood. However, as long as the heart continued to consume lactate, there was no anaerobic heat. On the other hand, when uptake of lactate by the myocardium from the blood was reversed to output of lactate by the myocardium, a new anaerobic source of heat appeared. The mean anaerobic caloric value of lactate formation by the myocardium was approximately $50 \mathrm{cal}$ per mmole lactate.

Anaerobic heat and lactate output occurred uniformly when $\mathrm{O}_{2}$ consumption was reduced to below $2.5 \mathrm{ml}$ per $100 \mathrm{~g} \times$ minutes. Below this level of aerobic metabolism, anaerobic metabolism accounted for 5 to $60 \%$ of the total metabolic rate.

Initiation of anaerobic heat production by the myocardium was not dependent upon the existence of myocardial hypoxia. Anaerobic heat also accompanied lactate output by the myocardium induced by alkalization of the blood without decrease in myocardial $\mathrm{O}_{2}$ consumption or increase in coronary venous blood lactate/pyruvate ratio.

\section{References}

1. Lusk, G. Analysis of the oxidation of mixtures of carbohydrate and fat. J. biol. Chem. 1924, 59, 41.

2. Neill, W. A., H. J. Levine, R. J. Wagman, J. V. Messer, N. Krasnow, and R. Gorlin. Left ventricular heat production measured by coronary flow 
and temperature gradient. J. appl. Physiol. 1961, 16,883 .

3. Van Slyke, D., and J. M. Neill. The determination of gases in blood and other solutions by vacuum extraction and manometric measurement. J. biol. Chem. 1924, 61, 523.

4. Huckabee, W. E. Control of concentration gradients of pyruvate and lactate across cell membranes in blood. J. appl. Physiol. 1956, 9, 163.

5. Wyman, J., Jr. The heat of oxygenation of hemoglobin. Advanc. Protein Chem. 1948, 4, 467.

6. Ibsen, K. H., E. L. Coe, and R. W. McKee. Some factors influencing respiration and glycolysis in
Ehrlich ascites tumor cells. Cancer Res. 1960, 20, 1399.

7. Bing, R. J. The metabolism of the heart. Harvey Lect. 1954-55, 50, 27.

8. Meyerhof, O. Energy relationships in glycolysis and phosphorylation. Ann. N. Y. Acad. Sci. 1944, 45, 377.

9. Neill, W. A., N. Krasnow, H. J. Levine, and R. Gorlin. Myocardial anaerobic metabolism in intact dogs. Amer. J. Physiol. 1963, 204, 427.

10. Burk, D. The free energy of glycogen-lactic acid breakdown in muscle. Proc. roy. Soc. B. 1928-29, 104, 153. 